\title{
Determinants of Effectiveness of Staff Training Programmes- evidence from Sri Lanka Institute of Development Administration
}

\author{
Arjuna Wickramasinghe ${ }^{1}$
}

SLJDA 2015 (5): 58-78

\begin{abstract}
This study attempts to examine the determinants of effectiveness of staff training programmes conducted by SLIDA through analyzing the data derived from evaluation sheets administered among participants at the end of each training programme. Effective and efficient public sector is the foundation for a modern developed state which stimulates private sector to achieve productivity enhancement and to maximize welfare. Continuous quality improvement in public sector is imperative in producing effective and efficient service to the people. On the other hand is evident that as a percentage of the population Sri Lankan public sector is one of the largest in the world and service of the public sector is indispensible to steer the privet sector to achieve the development goals. With that in mind, Sri Lanka Institute of Development Administration (SLIDA), the premier institute established to conduct training of the Sri Lankan public sector, conducts around 150 training programmes annually to enhance the skills of the public sector employees covering both managerial level as well as non-managerial level officers. It is required to measure the effectiveness of such trainings in achieving better results at the end as well as to develop successful training programs in the future. A rigorous regression framework is employed to isolate the impact of each aspects relating to two main areas examined by the evaluation forms, namely, resource person evaluation and the course arrangement evaluation. For this purpose, evaluation records maintained for 141 courses and resource persons during the year of 2013 have been taken into account. Findings show that there are few factors that contribute to the effectiveness of a training programme, while many of the items do not have anticipated impact on the effectiveness of the training programme. This research will facilitate the decision makers for developing successful training programmes and for the resource persons to have self examinations on the standards that they should maintain.
\end{abstract}

Key words: attributes of the Resource person, Level of learning, applicability, subject knowledge

\section{Introduction}

Sri Lanka has one of the largest public sectors in the world in comparison to the population of the particular country. The total population of Sri

1 Arjuna Wickramasinghe belongs to Sri Lanka Administrative Service and currently working as the Assistant Director (Examination) at Sri Lanka Institute of Development Administrative .He holds a M.A. (Economics) degree from University of Kelaniya and B.A. (Economics Special) degree from University of Colombo. 
Lanka is around 201,271,467 and the public sector employment is around 1.3 million. Put in another way 1 in every 15 persons is a public sector employee in Sri Lanka. Normally, it is 1 in every 250 or 300 in another country in the world. For the year 2013 too Sri Lanka has been able to maintain a 7.3 present growth rate and for maintaining that trend , the contribution of the private sector as well as public sector definitely play vital roles. Private sector is the sector that propels the development of the country while the public sector must steer the privet sector on the development path towards development objectives. In achieving that efficiency and the effectiveness of the public sector is a must.Sri Lanka Institute of Development Administration is the main training institute established for conducting training programmes for the Sri Lankan public sector. SLIDA had been established as the Academy of Administrative Studies to handle training matters of the staff grade government officials. In 1979, the Academy was renamed as Sri Lanka Institute of Development Administration and one of the main objectives of which lay down as "develop through training knowledge, skills and behavior in public officers which are necessary for the effective performance of their official duties." [SLIDA act. No. 9 of 1982 3(a)]

In other words SLIDA was established to develop human resource in the Sri Lankan public sector, through designing and conducting quality training program in the induction level and in the capacity building level as well. (Sri Lanka Institute of Development Administration, Welcome to SLIDA Sri Lanka: An Introduction for the Overseas Participants,2014) The scope of SLIDA has been widened in the year 2012 with the amalgamation of the Public Sector Training Institute which was functioning under the Ministry of Public Administration and Home Affairs of which the main responsibility was to conduct training programmes for the nonstaff grade officers in the public sector of Sri Lanka. Latest statics show that more than 30,000 officers have been undergoing training in SLIDA yearly. There were 66 and 75 training programmes conducted for the Staff grade officers and Non staff grade officers respectively in the year 2013.

National Human Resource and Employment policy for Sri Lanka has been prepared in the year 2012 in anticipating a foster human resource development in the country which would propel the development in the country in socio economic aspect. “The Sri Lanka Institute of Development Administration (SLIDA) will cover the training programmes for executive grades, and will receive the major emphasis for improvements. The Public Service Training Institute (PSTI) may be developed into a fully pledged training institute for non-executive grades." (Secretariat for senior ministers, 2012, pp37). Now, the importance of SLIDA has been extensively expanded after amalgamating the PSTI with SLIDA. 
The importance of SLIDA has been correctly identified by the high level policy makers and 50 acre land has already been allocated by the government to establish off Colombo SLIDA campus with modern residential and training facilities. At the moment Initial Environment Assessment (IEA) has already been conducted and sketched layout has been on the table for the discussion.

Most courses in SLIDA use class room style teaching .The number of participants usually rangers from 20 to 40 in each class. However, there is new introduction to the teaching methods :Virtual learning centers. There are 18 centers have been established island wide and selected training programmes which are conducted in the main training center SLIDA, simultaneity given to the participants who are gathered in the regional virtual learning centers, through virtual learning system. The trainer is delivering the programme to a set of participants in the main lecture room located in SLIDA while another set of participants are listening to the same lecture in a regional virtual training centre. Not only listen but also they can interact with the trainer as their wish. A technology video conferencing is used for delivering lectures to the virtual training centers.

In this paper at the very outset the present system of the evaluation of training programme is discussed briefly followed by the intention of the study .A comprehensive literature review is done for having a better idea about the components of evaluation structure. Then a step wise regression analysis is conducted to analyze the data collected through evaluation forms to identify the critical components of the evaluation. Regression analysis is administrated separately for the managerial training programmes separately to identify whether there is any difference between the results of the analysis. In the conclusion it is intended to give recommendations for the future developments.

\section{Background to the problem}

As one of the main institutions established for conducting training progarmmes to the public sector in Sri Lanka, the management as well as the policy makers have to have a very good idea on how well the institute is doing in terms of achieving objectives of the training programmes and whether the thousands of participants enhance the knowledge, skills and attitudes which are needed to have efficient and effective job performance.

It is expected that the training programmes must have a significant impact on the participants with regards to three aspects of learning: 
attitude, skills and knowledge. Attitudes refer to the way a person thinks and feel; skills are ability of do something well, while knowledge refers to the information, understanding and skills gained through education and experience. People who have the skills and could convert their knowledge in to useful value added ideas, goods and services are considered as a national wealth (Sri Lanka the emerging wonder of Asia unstoppable Sri Lanka 2020).After conducting training programme a right attitude must be developed among the participants and the level of skills and knowledge has to be increased by the training intervention.

At present SLIDA training programmes are evaluated at the end of the training session and the attributes of resource person and the attributes of course design and logistics are being evaluated using 5 scales. Namely: poor, below average, average, above average and excellent. There are 10 and 9 characteristics are considered for evaluating the previous and the later respectively. Figure 1.1 shows the aspects covered under the current evaluation model.

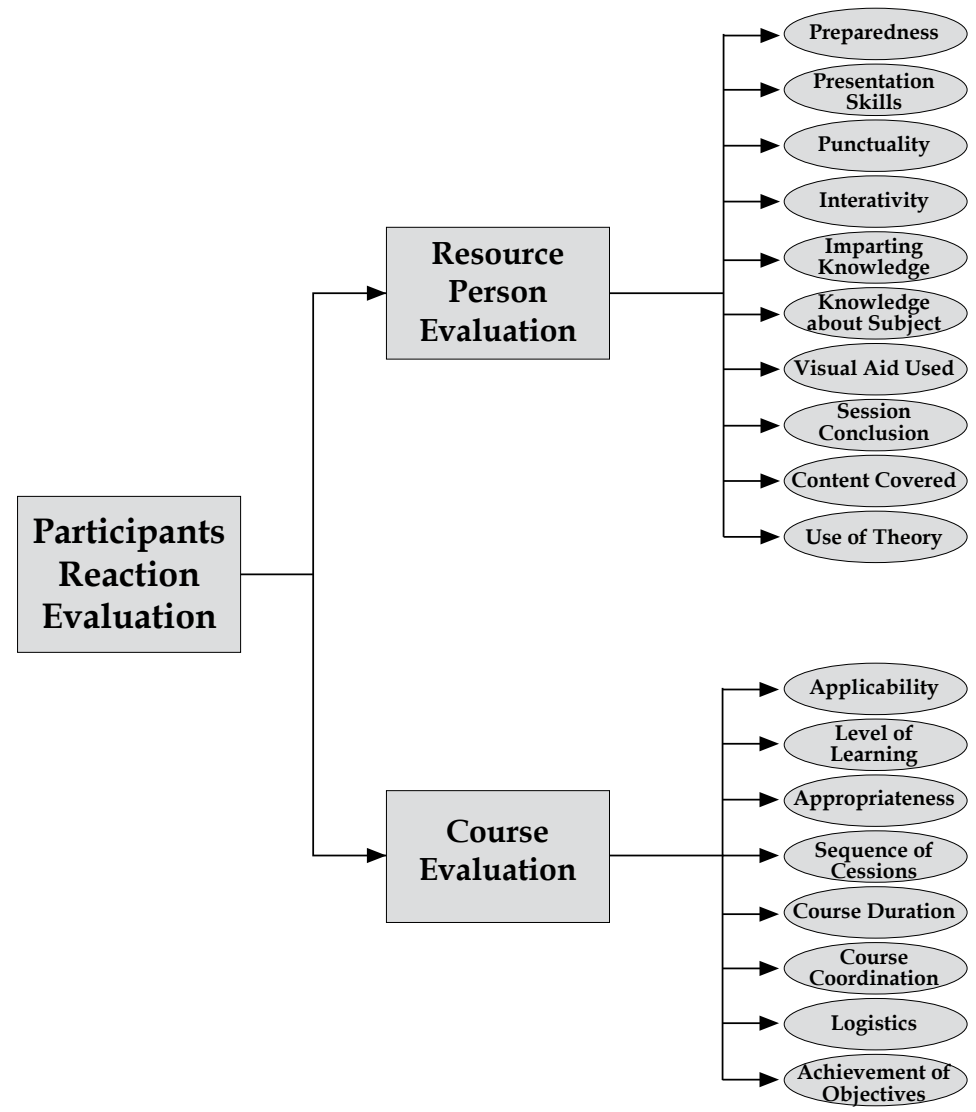

Figure 1 content of the current programme evaluation sheets 
If the current evaluation system recorded above 4 , in other words above average, for both resource person and for the course, considered as the satisfactory level. If a resource person gets lower than 4 , will be advised to develop his skills and knowledge by the Director General SLIDA. If a training programme gets lower than 4 , the course curriculum and the logistic arrangements will be revisited by the Design and Delivery committee consists of expert panel of SLIDA.

Although , being merely a gauge of customer satisfaction which evaluates the effectiveness of the training programme from the participants point of view, the current evaluation system will give an indication to the authorities whether the training programmewas on the right path or not.

\section{Objectives of the study}

This Study contains 4 objectives.

1. To explore the salient factors affecting to obtain a better reaction for the Course from the participants

2. To explore the salient factors affecting to obtain a better reaction for the Resource person from the participants

3. To explore is there a difference between reaction results of the managerial and no managerial training programmes in terms of course and resource person evaluations.

4. The areas needed to be considered when delivering a lecture

5. The areas should be prioritize when designing a course

The major research question in this research to explore what type of factors to be considered to obtain better reaction for course content and resource person attributes and also to discuss whether there is a difference in the course evaluation in the managerial and non managerial training programmes and also to explore what are the salient areas to be considered when delivering a lecture and specifically what areas to be prioritize when designing a course.

\section{Literature review}

For the development of human resource training is a strategically indispensible function in any organization.Training defined as set of activities focusing to learning skills attitudes and knowledge among the employees of an organization to improve their job performance and contribute to the achievement of the organizational goals .Richard McBain 
hasidentified training as: one of the mostinfluential methods for enhancing the productivity of individuals and communicating organizational goals to new personnel(Mcbain,2004).Gary Desslerbelieves that any training programme should be based principally on three stages; Planning Stage: need analysis, Implementation Stage: content of the training programme and learning/training methods applied and evaluation Stage: evaluation of the success or failures of the training programme(Dessler, 2012).

Although, many organizations often go into details of the planningandimplementation stages, the majority of organizations do not evaluate programmesorthe evaluation of training results is not mostly being done in a proper way (Saari, 1988). Most of the training institutions take decisions on the training programmes without a proper administration of the training evaluation results. Kirkpatrick's model is the most commonly used framework in evaluating the training effectiveness. Kirkpatrick introduced four steps for evaluating a training programme: Reaction, Learning, Behavior and Results. If the training programmes are going to be effective they must meet the needs of the participants (Kirkpatric,2006).One of the methods to measure the effectiveness of a training programme is to analyses the performance appraisal forms. The purpose of teaching is to bring about desired change in the learner behavior. In other words training should make a difference in the trainee. This change is usually brought in by the trainer or the instructor. But it is not an easy task to accomplish. The characteristics or qualities of the trainer play a pivotal role in the change in the behaviour of the trainee (Davies,1971).

There are 10 qualities of the resource person have been identified as the core competencies of a resource person in the training evaluations of SLIDA. For this research also it is decided to utilize thesecompetenciesnamely; preparedness, presentation skills, punctuality, imparting knowledge, knowledge about subject, visual aid used, session conclusion, content covered and use of theoryas the main areas to measure the competencies of the resource persons.

A set of scholars have conducted a research to identify whether the preparedness or the passion of the venture capitalist helped there investment decision. They found out that the preparedness is one of the most salient characters that helped to take a decision for venture capitalists (Xiao-Ping, Xin Yao and Suresh,1990). The retrieval system in the brain is stimulated if the incoming messages are structured properlyfor the trainees by the instructor.Clear sequential presentation of the ideas is necessary for that. In achieving this task adequate preparation of the instructor is the only way (Jinks, 1979).Effective presentation skills foster 
the learning of trainees by establishing clear communication and helping traineesengage in the learning process (Alshare and Hindi, 2004). In examination the importance of presentation skills in the class room through the students and instructors perspective, they found that the students and instructors agreed that main component of the presentations isto improve communication skills. However, the two groups differed on ranking the presentation evaluation. Whileinstructors ranked "thecontent of presentation" in the first place, students ranked "the organization of the presentation" as their first choice. Both groups, however, agreed that 'well-organized presentation' and 'enjoyable content'are the two most important measures of presentation effectiveness.Louisiana State University has given guidance to the presenters in the participants' manual of the Public Training Programme to improve "Platform Skills. "Platform skills" are the skills that a presenter do physically when leading a presentation. In other words "platform skills" are what the audience sees and hears during a presentation. Interactivity during the session is another quality that enhances the quality of the training programme. Active participation of students in thelearning process is considered as an indispensible fact for developing higherorder cognitive skills and of changing attitudes (Louisiana State University,2011). A study done by L. A. Vandijk and W. M. G. Jochemsreviled that a change from a traditional lecture to a more interactive approach helped significant improvement in trainees' motivation to study.(VanDijk and Jochems,2002)

Another quality to be maintained by a resource person to improve his image in the arena of training ispunctuality .However;different cultural groups have different norms and practices regarding punctuality (Lawrence, Raivo and Abdessmad, 2011). They emphasis that the meaning "on time", depends largely on local norms, the nature of the meeting and the status of the persons involved. However, if a resource person comes late for a training programme by 5 minutes should be considered as late.

Imparting knowledge to adults is a way of suggesting to them that there is no alternate for continuous engagementwith the appropriate literature information." we must consider that enlightenment is only available to the mature and we should encourage our students to do the same. Our aim must be to help our students inform, enlighten and enrich themselves.."( Sorokas, 2005, p13-14)Basically, trainees / students learningisa function of trainer/teacher quality. Theorists have conceptualized teacher quality as a set of specific knowledge areas and skills (Shulman, 1987). When discussing the trainer/teacher quality gap, Authorities tend to focus merely on paper qualification and experience. Apart from that, consideration on trainers/teachers' academic skills 
such as presentation, time management, reading, revising writing etc. is a must to minimize the trainer/teacher quality gap (Wane,2002).

Effective use of audio visuals describe as a must for a good training programme (Michalak and Yager, 1979). They emphasize that, "trainers should never let gimmicks interfere with their presentation. If the audio visuals are poorly prepared, they will have a negative impact on the programme. However, Modern, gimmicky visual aids can give an impression of slickness and appear 'with it', but they can never replace the empathetic journey into knowledge offered by true teacher." (Michalak and Yager, 1979, pp 111-112)

The closing of the training session most likely attracts a minimum attention in a training process. Normally, at the end of a training session Instructors hustle to finish the session, and participants want to leave the room as soon as possible. However, well-structured closing activities will definitely have a huge impact on the participants as they complete the training session and again when they return to their respective agencies. "Closing activities provide closure to instruction, tie up loose ends, summarize the highlights of training, and challenge participants to practically apply what they have learned, suggest appropriate follow-up, and make transitions"(National Victims Assistance Acadamy,USA,2002,pp8-1).If a trainer unable to conduct evaluation and to summarize the training session at the session conclusion it reflects disinterest, lack of professionalism and an indication of a non-caring attitude (FAO Corporate Document Repository).Sometimes trainers tend to cover the topics of the sessions in a very shorter period time. In contrast it will be adversely affected to the learning .Content covered is not always content learned (Clark,2010). When a trainee says content has been covered, he is referring to a one of the most commonly used instructional architectures-"show and tell", that involves a lecture supported by a presentation. Ruth suggested havinga "stair-step architecture", which uses traditional sequence of explanation, example or demonstration and practice with feedback in order to transform "content covered" in to "content learned". There should be a proper balance in between practical and theoretical knowledge in a training programme. "Both practice and theoretical experiences go hand in hand and each has their own significance. At every level, in an organization, where theoretical experience helps the individual to comprehend the basic notions, practice knowledge enables them to execute plans and strategies in the most effective manner" (Goel,2010) 
Not only the qualities, skills and knowledge of resource person but also the characteristics of the course design and the logistics do have a pivotal role in delivering a successful training programme. SLIDA evaluates the course design under 8 main teams. They arenamely, applicability, level of learning, appropriateness, sequence of sessions, courseduration, logistics and achievement of objectives.

Levels of learning refer to competencies a learner can achieve. Learning process can be divided in to 4 stages. They are; awareness, knowledge/ understanding, applying the knowledge on the job and finally skills development. "Training and education will be most effective if learning activities are fitting with and support this sequence. Each level in the sequence reflects different desired outcomes and requires different teaching strategies methodologies"(Rycus\& Hughes,2001)

Levels of learning refer to competencies a learner can achieve. Learning process can be divided in to 4 stages. They are; awareness, knowledge/ understanding, applying the knowledge on the job and finally skills development."Training and education will be most effective if learning activities are fitting with and support this sequence. Each level in the sequence reflects different desired outcomes and requires different teaching strategies methodologies"(Rycus and Hughes,2001,pp3-5)

Level 1 describes the scope of the training and the desired outcome to be achieved after the implementation of the training. This enhances the trainees' conceptual framework on the subject or the information which he is going to be acquired at the end of the programme.There are 2 stages in the level 2, the acquisition of knowledge and the development of understanding. The acquisition of knowledge stage offers accurate information on the topic while in the development understanding stage helps trainees to strengthen the relationship among the fundamentals of knowledge learnt by them. Appling the knowledge means the trainee can have a better idea about the concepts learned and could understand the relationships between the concept. The main benefit of this stage is the trainee could generalize the information acquired during the first 2 stages to other scenarios in solving problems. Finally,skills development emphasizes the applicability in to the respective jobs of the trainees while overcoming barriers in the job environment.

Theothercharacteristics measured throughapplicability, appropriateness, sequence of sessions, course durationand achievement of objectives can be positioned within the broader frame of course design and course coordination and logistics can be fit into the big picture of logistics. 
In order to prepare an effective course design it is a must to have a proper understanding about the trainees, what the trainer wants to have learnt by the trainees and finally and strategies of planning session. Good lesson plan is the road map which tells the trainer from the opening remarks up to final examination (if any) of the training programme. On the other hand clear lesson plan creates a logical systematic learning process which ensures the trainees will get maximum out of the training(Shrewder and Warner,2006).An effective training program has a beginning, middle, and an ending, whether it is a half-day session or a month-long program. Normally, a training program begins with ice-breaking or getting-toknow-you activities and ends with planning for the future and evaluating the program. The training program should follow a logical sequence, both in the individual sessions and in the overall course of the program (Circle of Rights).

(Michalak and Yager, 1979) describe 14 techniques that help to develop effective presentation skills of a trainer. They emphasize the necessity of give listeners signals to help them follow the idea of trainer, do not state off on the wrong foot(I really do not know why I was asked to do a presentation today) ,keep the conclusion short, be alert to the audience, maintain eye contact, vary the speed, make sure that everyone in the room can hear, use natural gesture, avoided putting the trainers hand near his / her face, use pose effectively, refrain from talk from notes, eliminate bad habits, never memorize the presentation and continuous practice.( Michalak and Yager, 1979,pp108-110)

\section{Methodology}

Primary data collected through the programme evaluation forms, in respect of Managerial and Non Managerial training programmes for the year 2013 is selected for this research. There were 33025 evaluation sheets available for the resource person evaluations for the year 2013 while there were 4265 evaluation sheets for the course evaluation. Scores given under these 2 sections have been aggregated and analysis has been done for the 141 course, 66 managerial training programmes and 75 non- managerial training programmes, the total number of programmes conducted under each category for the year 2013.

Multiple regression analysis is used to analyze the data and following model is used to determine the Dependent Variable and the Independent Variables. 


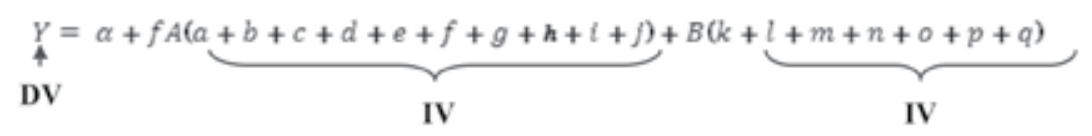

Where,

$\mathrm{Y}=$ Level of learning

$A=$ attributes of Resource person

$\mathrm{B}=$ Attributes of course (design

$\&$ logistics)

$\mathrm{a}=$ Preparedness

$b=$ Presentation skills

$c=$ Punctuality

d= Interactivity

$\mathrm{e}=$ Imparting Knowledge

$\mathrm{f}=$ Knowledge about subject

$\mathrm{g}=$ Visual aid used

$\mathrm{h}=$ Session conclusion

$\mathrm{i}=$ Content covered

$\mathrm{j}=$ Use of theory

$\mathrm{k}=$ Applicability

$1=$ Appropriateness

$\mathrm{m}=$ Sequence of sessions

$\mathrm{n}=$ Course duration

$\mathrm{o}=$ Course Coordination

$\mathrm{p}=$ Logistics

$\mathrm{q}=$ achievement of objectives

$a=$ Intercept

It is indispensible assess whether there is a encasement of learning happenedafter a training programme to assess whether there is learning took place during the training programme, the most appropriate method is to conduct an examination (Kirkpetric,2006) However, for this research the comment of trainees on the level of learning is taken in to account to assess the learning enhancement. Assessing knowledge gain through the feedback forms is not so uncommon in the research arena.(Nausheen, Jalil, Anwer\&Akhter,2010) 
Cronbach's alpha is used as a measurement of internal consistency, of the Items in the questioner. The Cronbach's alpha for the 18 items is .945 which is higher than .80 and considered as a good reliability. When considering the Cronbach'salpha :when item deleted, no item can be deleted except the logistics. However, if this item (logistics) deleted, increment of the Cronbach's alpha is .001 which is negligible and decided to keep the item.

Table 01

\begin{tabular}{|c|c|c|}
\hline \multicolumn{3}{|c|}{ Reliability Statistics } \\
\hline $\begin{array}{c}\text { Cronbach's } \\
\text { Alpha }\end{array}$ & $\begin{array}{c}\text { Cronbach's } \\
\text { Alpha Based on } \\
\text { Standardized } \\
\text { Items }\end{array}$ & N of Items \\
\hline .945 & .958 & 18 \\
\hline
\end{tabular}

For this research stepwise multiple regression has been used to eliminate insignificant IVs and to keep most important IVs for the regression model.In stepwise multiple regression, the independent variables are entered according to their importance of statistical contribution in explaining the variance in the dependent variable.Stepwise regression is designed to find the most prudent set of predictors that are most effective in predicting the dependent variable.

When conducting the step wise multiple regression, for Managerial training programmes and non-Managerial training programmes, 3 and 4 IVs have been identified as the most vital IVs for the 2 models respectively. 
Table 02

Variables Entered / Removed ${ }^{a}$

\begin{tabular}{|c|c|c|c|c|}
\hline Course Type & Model & $\begin{array}{c}\text { Variables } \\
\text { Entered }\end{array}$ & $\begin{array}{l}\text { Variables } \\
\text { Removed }\end{array}$ & Method \\
\hline \multirow[t]{3}{*}{ Managerial } & 1 & Achif_object & & $\begin{array}{c}\text { Stepwise (Criteria: } \\
\text { Probability-of-F- } \\
\text { to-enter }<=050 . \\
\text { Probability-of-F-to- } \\
\text { remove }<=100 \text { ) }\end{array}$ \\
\hline & 2 & Appropriate & & $\begin{array}{c}\text { Stepwise (Criteria: } \\
\text { Probability-of-F- } \\
\text { to-enter<= 050. } \\
\text { Probability-of-F-to- } \\
\text { remove }>=100 \text { ) }\end{array}$ \\
\hline & 3 & Applicability & & $\begin{array}{c}\text { Stepwise (Criteria: } \\
\text { Probability-of-F- } \\
\text { to-enter<= 050. } \\
\text { Probability-of-F-to- } \\
\text { remove }>=100 \text { ) }\end{array}$ \\
\hline \multirow[t]{4}{*}{$\begin{array}{c}\text { Non } \\
\text { Managerial }\end{array}$} & 1 & Achif_object & & $\begin{array}{c}\text { Stepwise (Criteria: } \\
\text { Probability-of-F- } \\
\text { to-enter<= 050. } \\
\text { Probability-of-F-to- } \\
\text { remove }<=100 \text { ) }\end{array}$ \\
\hline & 2 & Appropriate & & $\begin{array}{c}\text { Stepwise (Criteria: } \\
\text { Probability-of-F- } \\
\text { to-enter<= 050. } \\
\text { Probability-of-F-to- } \\
\text { remove }>=100) .\end{array}$ \\
\hline & 3 & Sub_know & & $\begin{array}{c}\text { Stepwise (Criteria: } \\
\text { Probability-of-F- } \\
\text { to-enter<=050. } \\
\text { Probability-of-F-to- } \\
\text { remove }>=100) .\end{array}$ \\
\hline & 3 & Applicability & & $\begin{array}{c}\text { Stepwise (Criteria: } \\
\text { Probability-of-F- } \\
\text { to-enter<= 050. } \\
\text { Probability-of-F-to- } \\
\text { remove }>=100) .\end{array}$ \\
\hline
\end{tabular}

a. Dependant Variable: Learning_Enhan 
Table 03

Model Summary

\begin{tabular}{|c|c|c|c|c|c|}
\hline Course type & Model & R & R. Square & $\begin{array}{c}\text { Adjusted } \\
\text { R Square }\end{array}$ & $\begin{array}{c}\text { Std. Error } \\
\text { of the } \\
\text { Estimate }\end{array}$ \\
\hline \multirow{3}{*}{ Managerial } & 1 & $.972^{\mathrm{a}}$ & .944 & .944 & .160 \\
& 2 & $.977^{\mathrm{a}}$ & .955 & .954 & .145 \\
& 3 & $.979^{\mathrm{a}}$ & .958 & .956 & .142 \\
\hline \multirow{3}{*}{ Non } & 1 & $.838^{\mathrm{a}}$ & .702 & .698 & .173 \\
Managerial & 2 & $.864^{\mathrm{a}}$ & .746 & .739 & .161 \\
& 3 & $.878^{\mathrm{a}}$ & .770 & .760 & .154 \\
& 4 & $.889^{\mathrm{a}}$ & .791 & .779 & .148 \\
\hline
\end{tabular}

a. Predictors (Constant) Achiof_object

b. Predictors: (Constant), Achiof_object Appropriate

c. Predictors: (Constant), Achiof_object, Appropriate, Applicability

d. Department Variable: Learning_Enhan

e. Predictors: (Constant), Achiof_object, Appropriate, Sub know

f. Predictors: (Constant), Achiof_object Appropriate, Sub_know Applicability

$\mathrm{R}$ square explains the amount of the variance in the dependent variable (Learning Level). In this model the R square scores for all predictors (IVs) for Managerial programmes and Non-managerial programmes went beyond0.94and 0.70 , respectively. In other words it is a very noteworthy score which explains that all3 predictors for Managerial programmes and all 4 predictors for Non-Managerial programmesexplain more than 94 percent and 70percent respectively, of the variance of the DV.This is a strong evidence for the existence of the models.

ANOVA tests the statistical significance of the each model at each step. $P$ values or in other words significance values are less than 0.05 for each and every step. This is strong evidence for the rejection of the Null hypothesis, which is the model, has no explanatory power. 
Table 04

ANOVA $^{a}$

\begin{tabular}{|c|c|c|c|c|c|c|c|}
\hline Course type & Model & & $\begin{array}{l}\text { Sum of } \\
\text { Squares }\end{array}$ & df & $\begin{array}{l}\text { Mean } \\
\text { Square }\end{array}$ & $\mathbf{F}$ & Sig \\
\hline \multirow{9}{*}{ Managerial } & \multirow{3}{*}{1} & Regression & 27.981 & 1 & 27.981 & 1087.243 & $.000^{\mathrm{b}}$ \\
\hline & & Residual & 1.647 & 64 & \multirow[t]{2}{*}{.026} & & \\
\hline & & Total & 29.628 & 65 & & & \\
\hline & \multirow{3}{*}{2} & Regression & 28.299 & 2 & \multirow{3}{*}{$\begin{array}{r}14.149 \\
.021\end{array}$} & \multirow[t]{3}{*}{670.541} & \multirow[t]{3}{*}{$.000^{c}$} \\
\hline & & Residual & 1.329 & 63 & & & \\
\hline & & Total & 29.628 & 65 & & & \\
\hline & \multirow{3}{*}{3} & Regression & 28.384 & 3 & \multirow{3}{*}{$\begin{array}{r}9.461 \\
.020\end{array}$} & \multirow[t]{3}{*}{471.506} & \multirow[t]{3}{*}{$.000^{\mathrm{d}}$} \\
\hline & & Residual & 1.244 & 62 & & & \\
\hline & & Total & 29.628 & 65 & & & \\
\hline \multirow{12}{*}{$\begin{array}{l}\text { Non } \\
\text { Managerial }\end{array}$} & \multirow{3}{*}{1} & Regression & 5.144 & 1 & \multirow{3}{*}{$\begin{array}{r}5.144 \\
.030\end{array}$} & \multirow[t]{3}{*}{171.685} & \multirow[t]{3}{*}{$.000^{\mathrm{b}}$} \\
\hline & & Residual & 2.187 & 73 & & & \\
\hline & & Total & 7.332 & 74 & & & \\
\hline & \multirow{3}{*}{2} & Regression & 5.471 & 2 & \multirow{3}{*}{$\begin{array}{r}2.735 \\
.026\end{array}$} & \multirow[t]{3}{*}{105.846} & \multirow[t]{3}{*}{$.000^{c}$} \\
\hline & & Residual & 1.861 & 72 & & & \\
\hline & & Total & 7.332 & 74 & & & \\
\hline & \multirow{3}{*}{3} & Regression & 5.646 & 3 & \multirow{3}{*}{$\begin{array}{r}1.882 \\
.024\end{array}$} & \multirow[t]{3}{*}{79.291} & \multirow[t]{3}{*}{$.000^{\mathrm{e}}$} \\
\hline & & Residual & 1.685 & 71 & & & \\
\hline & & Total & 7.332 & 74 & & & \\
\hline & \multirow{3}{*}{4} & Regression & 5.799 & 4 & 1.450 & \multirow[t]{3}{*}{66.183} & \multirow[t]{3}{*}{$.000^{\mathrm{f}}$} \\
\hline & & Residual & 1.533 & 70 & .022 & & \\
\hline & & Total & 7.332 & 74 & & & \\
\hline
\end{tabular}
a. Dependant Variable: Learning_Enhan
b. Predictors: (Constant). Achiof_Object
c. Predictors: (Constant). Achiof_Object, Appropriate
d. Predictors: (Constant). Achiof_Object, Appropriate, Applicability
e. Predictors: (Constant). Achiof_Object, Appropriate, Sub_know
f. Predictors: (Constant). Achiof_Object, Appropriate, Sub-know, Applicability 
Table 5

\begin{tabular}{|c|c|c|c|c|c|c|c|c|c|c|c|c|c|c|}
\hline \multirow[b]{2}{*}{$\begin{array}{l}\text { Course } \\
\text { Type }\end{array}$} & \multirow{2}{*}{\multicolumn{2}{|c|}{ Model }} & \multicolumn{2}{|c|}{$\begin{array}{l}\text { Unstandardized } \\
\text { Coefficients }\end{array}$} & \multirow{2}{*}{\begin{tabular}{|c|}
$\begin{array}{c}\text { Standard- } \\
\text { ized } \\
\text { Coefficients }\end{array}$ \\
Beta \\
\end{tabular}} & \multirow[b]{2}{*}{$\mathrm{t}$} & \multirow[b]{2}{*}{ Sig. } & \multicolumn{2}{|c|}{$\begin{array}{l}95.0 \% \text { Confidence } \\
\text { interval for B }\end{array}$} & \multicolumn{3}{|c|}{ Correlations } & \multicolumn{2}{|c|}{$\begin{array}{l}\text { Collinearity } \\
\text { Statistics }\end{array}$} \\
\hline & & & B & Std. Error & & & & $\begin{array}{l}\text { Lower } \\
\text { Bound }\end{array}$ & $\begin{array}{l}\text { Upper } \\
\text { Bound }\end{array}$ & $\begin{array}{l}\text { Zero- } \\
\text { Order }\end{array}$ & Partial & Part & $\begin{array}{l}\text { Toler- } \\
\text { ance }\end{array}$ & VIF \\
\hline \multirow[t]{9}{*}{ Managerial } & \multirow[t]{2}{*}{1} & (Constant) & .030 & .113 & & .262 & .794 & -.195 & .254 & .972 & .972 & .972 & & \\
\hline & & Achiof_Object & 1.004 & .30 & .972 & 32.973 & .000 & .943 & 1.065 & .972 & .627 & .170 & 1.000 & 1.000 \\
\hline & \multirow[t]{3}{*}{2} & (Constant) & -31 & -103 & & -303 & .763 & -237 & .175 & & & & & \\
\hline & & Achiof_object & 634 & .099 & .614 & 6.385 & .000 & .436 & .832 & .972 & .627 & .170 & .265 & 3.766 \\
\hline & & Appropriate & .374 & .096 & .373 & 3.880 & .000 & .181 & .566 & .962 & .439 & .104 & .265 & 3.766 \\
\hline & \multirow[t]{4}{*}{3} & (Constant) & -.056 & .101 & & -.555 & .581 & -.259 & .146 & & & & & \\
\hline & & Achiof_object & .583 & .100 & .564 & 5.835 & .000 & .383 & 3783 & .972 & .595 . & 152 & .252 & 3.960 \\
\hline & & Appropriate & .242 & .114 & .241 & 2.127 & .037 & .015 & .469 & .962 & .261 & .055 & .259 & 3.860 \\
\hline & & Applicability & .184 & .089 & .187 & 2.062 & .043 & .006 & .363 & .947 & .253 & .054 & .218 & 4.568 \\
\hline \multirow{14}{*}{$\begin{array}{c}\text { Non } \\
\text { Managerial }\end{array}$} & \multirow[t]{2}{*}{1} & (Constant) & .955 & .253 & & 3.777 & .000 & .451 & 1.458 & & & & & \\
\hline & & Achiof_Object & .789 & .060 & .838 & 13.103 & .000 & .669 & .909 & .838 & .838 & .838 & 1.000 & 1.000 \\
\hline & \multirow[t]{3}{*}{2} & (Constant) & .703 & .245 & & 2.866 & .005 & .214 & 1.192 & & & & & \\
\hline & & Achiof_Object & .496 & .100 & .527 & 4.985 & .000 & .298 & .695 & .838 & .507 & .296 & .316 & 3.169 \\
\hline & & Appropriate & .352 & .099 & .376 & 3.555 & .001 & .154 & .549 & .812 & .386 & .211 & .316 & 3.169 \\
\hline & \multirow[t]{4}{*}{3} & (Constant) & -.011 & .352 & & -.031 & .975 & -.713 & .692 & & & & & \\
\hline & & Achiof_object & .397 & .102 & .422 & 3.888 & .000 & .193 & .601 & .838 & .419 & .211 & .275 & 3.632 \\
\hline & & Appropriate & .324 & .095 & .347 & 3.404 & .001 & .134 & .514 & .812 & .375 & .194 & .312 & 3.204 \\
\hline & & Sub_know & .273 & .100 & .202 & 2.719 & .008 & .073 & .474 & .671 & .307 & .155 & .585 & 1.709 \\
\hline & \multirow[t]{5}{*}{4} & (Constant) & -.200 & .346 & & -.577 & .566 & -.889 & .490 & & & & & \\
\hline & & Achiof_object & .252 & .112 & .268 & 2.243 & .028 & .028 & .477 & .838 & .259 & .123 & .210 & 4.772 \\
\hline & & Appropriate & .237 & .097 & .254 & 2.437 & .017 & .043 & .431 & .812 & .280 & .133 & .276 & 3.622 \\
\hline & & Applicability & .260 & .099 & .272 & 2.625 & .010 & .063 & .457 & .805 & .300 & .144 & .280 & 3.576 \\
\hline & & Sub-know & .285 & .097 & .211 & 2.950 & .004 & .092 & .478 & .671 & .333 & .161 & .584 & 1.713 \\
\hline
\end{tabular}

a.Department Variables: Learning_Enhan

For Managerial training programmes the largest standardize coefficient beta is .564, which is for Achieveof_object .Beta values for Appropriate and Applicability are .241 and .187 respectively. These values indicate that achieve_object is the highly contributed IV for the Level of learning and appropriateness and relevancy are lagging behind it.Fornon-managerial training programmes too, the most vital iv is the achievement of objective of which the standardize coefficient Beta value is .268. However, its contribution to the Level of learning (DV) of the Non Managerial training programme is less than that of in the Managerial training programmes Which is .564. Another noteworthy difference between managerial programmes and the Non Managerial programmes is the inclusion of the subject knowledge as IV.The contribution of the subject knowledge in the Non managerial training programme is.211.

When considering the Collinearity statistics, the tolerance value for all IVs are greater than .21 and the VIFs (Variance inflation factors) less than 5.If the tolerance is below .20 and the VIF greater than 10 it indicates the multiple correlation with other variables is high(Pallant,2007).If the multiple correlation with other variables is high it adversely affect to the reliability of the model. However, in this analysis such problem is not arise since the tolerance and the VIF values are well within the standard level. 
Table 6

Excluded Variables $^{\mathrm{a}}$

\begin{tabular}{|c|c|c|c|c|c|c|c|c|c|}
\hline \multirow{2}{*}{$\begin{array}{l}\text { Course } \\
\text { Type }\end{array}$} & \multirow[b]{2}{*}{ Model } & & \multirow[b]{2}{*}{ Beta In } & \multirow[b]{2}{*}{$\mathrm{t}$} & \multirow[b]{2}{*}{ Sig. } & \multirow{2}{*}{$\begin{array}{l}\text { Partial } \\
\text { Correlation }\end{array}$} & \multicolumn{3}{|c|}{ Collinearity Statistics } \\
\hline & & & & & & & Tolerance & VIF & $\begin{array}{l}\text { Minimum } \\
\text { Tolerance }\end{array}$ \\
\hline \multirow[t]{14}{*}{ Managerial } & 3 & Session_seq & $.142^{\mathrm{d}}$ & 1.954 & .055 & .243 & .123 & 8.123 & .050 \\
\hline & & Duration & $.051^{\mathrm{d}}$ & 1.160 & .251 & .147 & .349 & 2.861 & .051 \\
\hline & & Coordination & $-.075^{\mathrm{d}}$ & -1.095 & .278 & -.139 & .142 & 7.038 & .051 \\
\hline & & Logistics & $-.038^{\mathrm{d}}$ & -.912 & .365 & -.116 & .388 & 2.578 & .052 \\
\hline & & Preparedness & $.012^{\mathrm{d}}$ & .436 & .664 & .056 & .951 & 1.052 & .052 \\
\hline & & Presen_Skill & $.035^{\mathrm{d}}$ & 1.265 & .211 & .160 & .862 & 1.160 & .052 \\
\hline & & Punctuality & $.012^{\mathrm{d}}$ & .451 & .654 & .058 & .976 & 1.024 & .052 \\
\hline & & Intractivity & $.026^{\mathrm{d}}$ & .939 & .352 & .119 & .879 & 1.138 & .052 \\
\hline & & Impar-know & $.010^{\mathrm{d}}$ & .349 & .728 & .045 & .918 & 1.089 & .052 \\
\hline & & Sub-know & $.001^{\mathrm{d}}$ & .023 & .982 & .003 & .934 & 1.071 & .052 \\
\hline & & Visaid_used & $-.024^{\mathrm{d}}$ & -.899 & .372 & -.114 & .987 & 1.013 & .053 \\
\hline & & Conclusion & $.006^{\mathrm{d}}$ & .231 & .818 & .030 & .945 & 1.058 & .052 \\
\hline & & Con_coverd & $.001^{\mathrm{d}}$ & .019 & .985 & .002 & .942 & 1.062 & .052 \\
\hline & & Use of_theory & $.031^{\mathrm{d}}$ & 1.177 & .244 & .149 & .950 & 1.053 & .051 \\
\hline \multirow[t]{13}{*}{$\begin{array}{c}\text { Non } \\
\text { Managerial }\end{array}$} & 4 & Session_seq & $.081^{f}$ & .901 & .371 & .108 & .370 & 2.704 & .206 \\
\hline & & Duration & $.062^{f}$ & .919 & .361 & .110 & .663 & 1.507 & .176 \\
\hline & & Coordination & $-.006^{\mathrm{f}}$ & -.081 & .936 & -.010 & .534 & 1.871 & .197 \\
\hline & & Logistics & $-.040^{\mathrm{f}}$ & -.620 & .538 & -.074 & .719 & 1.390 & .203 \\
\hline & & Preparedness & $.018^{f}$ & .148 & .883 & .018 & .209 & 4.794 & .204 \\
\hline & & Presen_Skill & $-.068^{f}$ & -.554 & .581 & -.067 & .199 & 5.025 & .191 \\
\hline & & Punctuality & -.048 & -.500 & .619 & -.060 & .330 & 3.026 & .201 \\
\hline & & Intractivity & $-.070^{f}$ & -.602 & .549 & -.072 & .226 & 4.431 & .207 \\
\hline & & Impar_know & $-.064^{f}$ & -.484 & .630 & -.058 & .171 & 5.834 & .167 \\
\hline & & Visaid_used & $-.036^{f}$ & -.592 & .556 & -.071 & .816 & 1.225 & .209 \\
\hline & & Conclusion & $.040^{f}$ & -.455 & .650 & -.055 & .387 & 2.587 & .209 \\
\hline & & Con_coverd & $.065^{f}$ & -.626 & .534 & -.075 & .278 & 3.595 & .209 \\
\hline & & Use of_theory & $-.154^{\mathrm{f}}$ & -1.724 & .089 & -.203 & .362 & 2.759 & .199 \\
\hline
\end{tabular}

a. Dependant Variable: Learning_Enhan

b. Predictors in the Model: (Constant), Achiof_object, Appropriate, Applicability

f. Predictors in the Model: (Constant), Achiof_object, Appropriate, Sub_know, Applicability

When examine the residuals of the Managerial Training programmes and Non-Managerial training programmes 14 IVs and 12 IVs have been identified respectively as the least important IVs. The significant thing is that the Course coordination. Logistics and visual aid used have negative impact on the level of learning (DV) in the managerial programmes. While coordination, logistics, presentation skills, punctuality, interactivity, imparting knowledge, visual aid used, session conclusion, content covered and use of theory have been identified as the IVs that have a negative impact on the level of learning on the managerial programmes.

Considering above facts and figures it is suggested to re-arrange the models as follows

Managerial Training Programmes

$y=\alpha+.58 \mathrm{q}+.24 \mathrm{l}+.18 \mathrm{k}+\mathrm{e}$ 
Non- Managerial Training Programmes

$y=\alpha+.29 \mathrm{f}+.25 \mathrm{q}+.26 \mathrm{k}+.241+\mathrm{e}$

Where,

$\mathrm{y}=$ Level of Learning enhanced

$a=$ Intercept

$q=$ Achieve_object

$l=$ Appropriate

$k=$ Applicability

$f=S u b \_$Know

$e=$ error term

The Regression models for the Managerial and Non Managerial programmes can be clearly identified by following visual expressions.

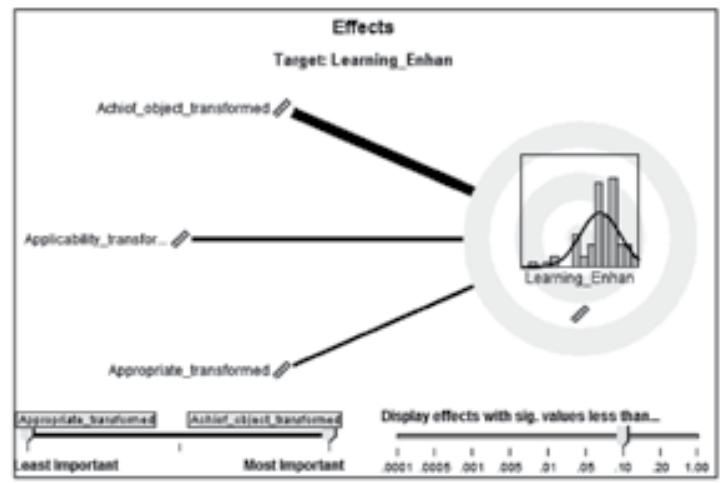

Figure 2 Regression model for the

Managerial Training Programmes

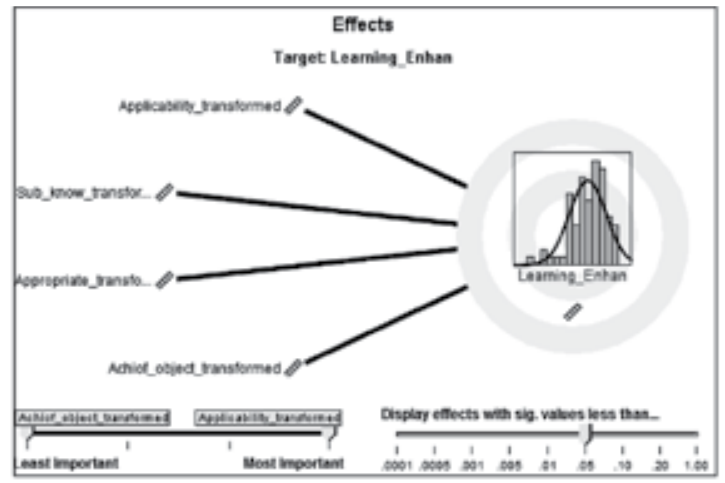

Figure 3 Regression model for the Non

Managerial Training Programmes 
When exploring the regression ofthe managerialprogrammes the main factor affects to the level of learning is the achievement of objective. If the achievement of objectiveincreased by 1 point the level of learning is enhanced by 58 percent. The second most important factor is the appropriateness. If the appropriateness is changed by 1 point the level of learning is changed by 28 percent. In contrast 1 point increase in the applicability of the training will affects to 18 percent increase in the level of learning.

The subject knowledge of the resource person is the main factor affects to the level of learning of the trainees when it comes to the regression of the non-managerial programmes. If the subject knowledge increased by 1 point the level of learning is enhanced by 29 percent. The second most important factor is the achievement of objectives. If the achievement of objectivesis changed by 1 point the level of learning is changed by 26 percent. In contrast 1 point increases in the applicabilityaffects to 25 percent increase in the level of learning.Appropriateness ofthe training programme is also makes a vital contribution to the level of learning of the trainees.A1 point increase in appropriateness, the level of learning is enhanced by 24 percent.

\section{Conclusion and recommendations}

The above facts and figures reveal that the participants of the managerial programmes do not pay much attention to the attributes of the resource persons in terms of enhancing level of learning. The achievement of course objectives and appropriateness are the main factors affect to the level of learning. Therefore the course design has a pivotal role in enhancing the knowledge among the participants. The authorities must pay attention to conduct a comprehensive formative analysis in the stage of the course design in order to have a successful managerial level training programme at the end. Not only that but also the authorities must pay attention to clustering the managerial groups according to the content of the programme.Eg.- a programme on policy paper writing may applicable to the managerial level officers in the ministries and departments but not to the officers in the divisional level administration. The other main factor which affects to the level of learning of themanagerial officers is the applicability. Hence, the authorities should consider designing programmes which are more practical and could be applied to the job environment of the respective officers.

On the other hand, non - managerial officers emphasize the importance of the subject knowledge of the resource person, one of the main 
attributes of a resource person, in improving the level of knowledge. This may happen that the non-managerial officers mainly selected to the government service from the results of the Ordinary level or the Advanced level qualifications and do not undergo a comprehensive induction programme at the very beginning of the carrier as the managerial level officers. They do not possess sufficient idea about the skills and knowledge indispensible to perform government sector tacks,so they may think that the knowledge of the resource person plays a pivotal role in improving their (trainees) knowledge. Apart from the subject knowledge achievement of objective, applicability and appropriateness are considered as the most significant factors that help to improve the level of learning.

Therefore, for managerial and non- managerial training programmes much effort must be put in to the designing stage of the course.While keep in mind that the managerial level officers considered achievement of objectives, appropriateness and applicably are the significant factors for improving level of learning. Thus, clustering the group is a must in order to achieve maximum out come from the training programme for the managerial level officers. While keep in mind that the subject knowledge of the resource person is very important to have a successful training programme for non- managerial officers. So, selecting trainers who are conversant in the respective subject area is must for non-managerial training programme.

Since this study is confined for evaluating the reaction of the participants which fulfills the $1^{\text {st }}$ level of Kirkpatrick's training evaluation, it is indispensible to conduct a comprehensive study to explore whether there is a change in the participants' behavior due to training programs,

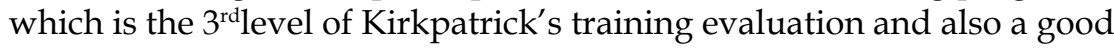
opportunity for a future research. On the other hand this study is limited to the data collected for the year 2013 in fact improved picture can be observed if a time series analysis will be done using at least data collected for 5 years.

\section{References}

Christine Edmunds.(2002), National Victim Assistance. June 2002.pp8-1

Circle of rights. Retrieved from https://www1.umn.edu/humanrts/edumat/IHRIP/ circle/toc.htm

Clark,Ruth Colvin.(2010). Evidence Based Training Methods : A Guide for Training Professionals, USA. American Society of Training and Development.

Davies,Ivor k.(1971). The Management of Learning, London.McGrew- Hill.

Dessler,Gray.(2012) Human Resource Management, Prentice hall 
FAO Corporate Document Repository, retrived from http://www.fao.org/docrep/w8088e/ w8088e03.htm\#section 1 principles and methods of training.

Goel,Rohtas."Theoretical Knowledge Vs Practical Skills" .The Economic Time. 12 May2010.

Khaled, Alshare , Nitham M Hindi (2004). “The Important of Presentation Skills in the Classroom", Journal of Computing Science in Colleges, vol.19 Issue 4, April 2004.pp6-15.

kirkparick ,Donald L \& kirkparick, James D K (2006). Evaluating Training Programs: The Four Levels. San Fransisco. Berrett-Koehler Publishers.

L.A. Van Dijk \& W.m.G. Jochems, (2002)."Changing a Traditional Lecturing Approach into Interactive Approach", International Journal of Engineering Education. Vol. 18 No.3.pp275-284.

Lawrence T. white, Raivo Valk \& Abdessamed Dialmy,(2011).What is the meaning of 'On Time' The Sociocultural Nature of Punctuality, Journal of Cross- Cultural Psychology,April 2011.42(3).pp482-493.

Lee S. shulman. (1987)" Knowledge and Teaching: Foundation of the New Reform". Harward Educational Review, Vol 57. No.1. Spring 1987.pp1-23.

McBain, Richard. (2004) Training effectiveness in evaluation. Braybooke Press.

Michael, Jinks(1979). Blandford Management Series:Training, Dovet.Blandford Press Ltd.

Michalak,Donald f. \&Yager Edwin G. (1979) Making the Training Process Work. New York. Harper \& Row Publishers.

Office of Human Resourse Management. (2011). Effective Presentation Skills. Participants Manual, Louisiana State University. LA.

Saari, Lise M. (1998) “A Survey of Management Training and Education Practices in U.S. Companies", Personal Psychology, 41 n4 p731-43 win 1998.

Secretariat for senior ministers, (2012), National Human Resource and Employment policy for Sri Lanka. Colombo.

Shrawder ,Jack H. \& Warner, David.(2006) "Planning a successful Lesson".Retrived from https://www.wwcc.wy.edu/facres/tfs/focalites/LessonPlan_Focalite.pdf.

Sorokas, Simon. (2005), “The Role of the University Teacher: Imparting knowledge or Providing Entertainment". Teaching Political science Series, No 2: How to Teach Political Science? The experience of First-time University Teachers Volume 2.Bratislava : Comenius University .Vol 2.pp11-14.

Sri Lanka Institute of Development Administration Act No. 09 of 1987.

Sri Lanka Institute of Development Administration,(2014) Welcome to SLIDA Sri Lanka: An Introduction for the Overseas Participants. Colombo.

Wayne, Andrew J.(2002)."Teacher Inequality: New Evidence on Disparities in Teachers' Academic Skills", Education Policy Analysis Archives. Vol 10.No.30. 13 June 2002.ppc 1-13.

Xiao-ping Chen, Xin Yao, \& Suresh Kotha. (1990) “A Persuasion Analysis of Venture Capitalists' Funding decisions", Academy of Management Journal Feb.2009 52:1 pp 199214. 